\title{
Coconut hispine beetle Brontispa longissima (Gestro) (Coleoptera: Chrysomelidae)
}

\author{
S.P. Singh ${ }^{1}$ and P. Rethinam ${ }^{1}$
}

\begin{abstract}
Coconut hispine beetle, Brontispa longissima (Gestro) was originally described from the Aru Islands (Maluku Province). It is native to Indonesia (Aru Islands, Maluku Province and possibly to Papua Province formerly known as Irian Jaya), and also to Papua New Guinea, including the Bismarck Archipelago, where it seldom causes serious problems. It has now spread widely in Asia, Australasia and Pacific Islands attacking not only coconut palm but also several other cultivated and wild palms. In recent times it has spread to Singapore, Vietnam, Nauru, Thailand, Maldives and Hainan Island (China). In the absence of natural antagonists it has become a very serious and devastating pest in new areas of its spread. It is feared that $B$. longissima will find its way from Maldives to Sri Lanka and southern parts of India to derail the economy of these important coconutgrowing regions of the world. Thus emergency operations are necessary to try to decimate it down in the Maldives. A number of natural enemies such as Hispidophila (Haeckeliania) brontispae Ferriere, Ooncyrtus podontiae Gahan, Trichogrammatoidea nana Zehntner, Tetrastichus brontispae Ferriere, Asecodes hispinarum Boucek, Chrysonotomyia sp., Metarhizium anisopliae (Metchnikoff) Sorokin, Chelisoches morio Fabricius, Oecophylla smaragdina (Fabricious), mites on adults (Anoplocelaeno sp. and Celaenopsis sp.), geckoes, skinks, tree frog and unidentified bacterial pathogen have been recorded. Biological control by introduction and enhancement of parasitoids- $A$. hispinarum and T. brontispae has proved very effective. Similarly spray of improved strains of entomopathogenic fungus, $M$. anisopliae has proved effective. Exploratory surveys for parasitoids in the original home of $B$. longissima are suggested.
\end{abstract}

Chemical control was recommended, but most of the insecticides recommended earlier have been phased out due to their harmful side effects. Though difficult to implement, use of tolerant cultivars, adoption of phytosanitory measures, and imposition of strict quarantine measures are also recommended. In addition, relatively safer pesticides could also be used to knock down the pest before biological control becomes operative and effective.

Key words: Coconut, Brontispa longissima, distrbution, natural enemies, Asecodes hispinarum, Tetrastichus brontispae, Metarhizium anisopliae, biological control, chemical control, phytosanitory measures, quarantine measures, tolerant cultivars.

\footnotetext{
1.Asian and Pacific Coconut Community (APCC), Jakarta, Indonesia Email: apcc@indonet.id
} 


\section{Introduction}

Coconut hispine beetle is also known as coconut beetle, coconut leaf hispid, New Hebrides coconut hispid, dorsalis palm leaf beetle, brontispe $\mathrm{du}$ cocotier, tweekleurige klapperbladkever and Kokosnussblattkäfer. Similarly, ever since its first description by Gestro in 1885 as Brontispa longissima, some workers have used different names such as B. froggatti Sharp, B. castanea Lea, $B$. reicherti Uhmann, $B$. simmondsi Maulik and Oxycephala longipennis Gestro which are all synonyms of $B$. longissima (Gestro). But, $B$. limbata (Waterhouse) from Mauritius is considered valid species. In Indonesia, many local varieties have been described from time to time such as var. longissima with brown elytra, originally described in Wolan (Maluku Province), and in Java; var. frogatti Sharp with almost black elytra, from New Britain and the Solomon islands; var. selebensis Gestro with a spindle-shaped, black marking on the suture of the elytra, originating from South and North Sulawesi, also from near Bogor and Java. Numerous forms, intermediate between the last two varieties were considered to occur in Sulawesi, Maluku and Papua Provinces. Fertile offsprings from longissima and selebensis crosses could be produced in the laboratory (Kalshoven, 1981). Generally, the colour of the adult varies geographically from reddish-brown in Java to almost black in the Solomon Islands, New Guinea and Papua Province (Indonesia). Considerable overlapping of these forms, which were for long regarded as distinct species, occurs (Lever, 1969). Some of these are probably merely local forms of more widely distributed species. However a thorough revision of this group is necessary in the entire distribution zone to critically analyze and determine the species, sub species, etc.

\section{Distribution of Brontispa longissima}

Coconut hispine beetle, B. longissima was originally described from the Aru Islands (Maluku Province). It is native to Indonesia (Aru Islands, Maluku Province and possibly to Papua Province formerly known as Irian Jaya) and also to Papua New Guinea, including the Bismarck Archipelago, where it seldom causes serious problems (CIBC, 1989). Its arrival in Tahiti (Cohic, 1961) has facilitated its further spread in Polynesia. In recent times it has invaded coconut palms in Republic of Vietnam, and Thailand. B. longissima has reached Ari Atil in Maldives from where it can easily spread to Sri Lanka and southern parts of India, if not contained. It is now distributed in Asia, Australia and Pacific Islands (Table 1) attacking not only coconut palm but also several other palms such as betel palm, Areca catechu; sago palm, Metroxylon sagu; Mexican fan palm, Washingtonia robusta; fox tail palm, Wodyetia bifurcata; Alexandra palm, Archontophoenix alexandrae, pygmy date palm, Phoenix roebelenii, nipa palm, Nypa fruiticans and several forms of cycads. In Australia it has been recorded on 27 native and exotic palms. Among the modes of spread of B. longissima, lack of strict quarantine on the movement of palms (particularly ornamental) is considered as a major factor.

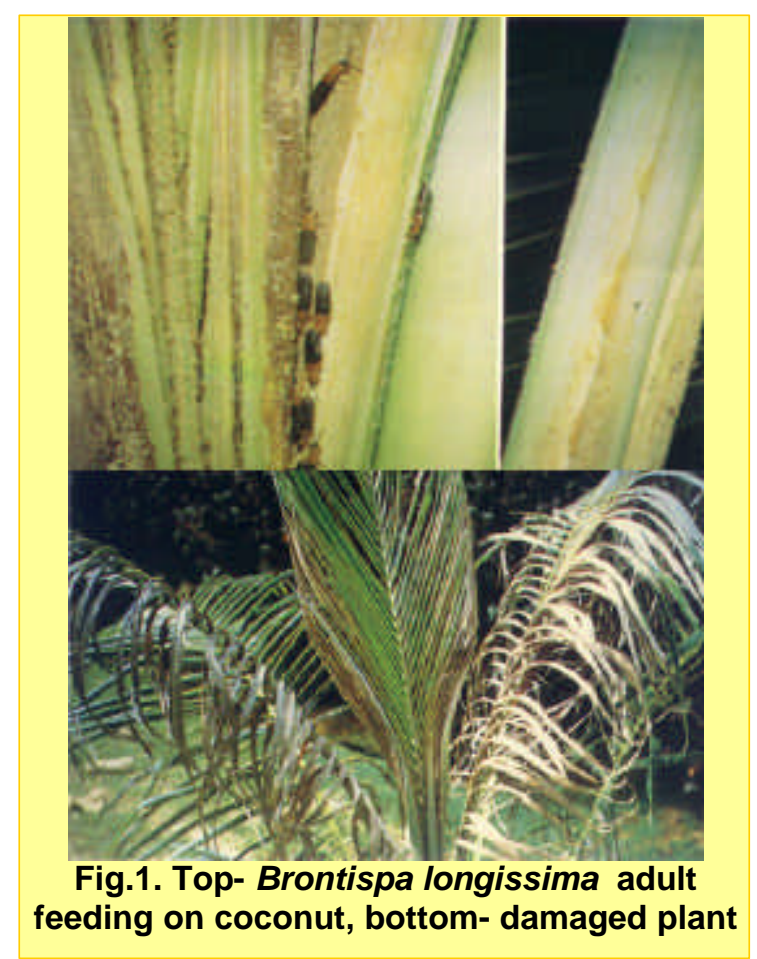


Table 1. Disrtibution of Brontispa longissima

\begin{tabular}{|c|c|}
\hline Place & Remarks \\
\hline China & $\begin{array}{l}\text { Reported from Shenzhen area of Guangdong } \\
\text { Province, spread to Hong Kong in 1988,also in } \\
\text { Hainan Islands }\end{array}$ \\
\hline Indonesia & $\begin{array}{l}\text { First reported in } 1885 \text { from Indonesia (Aru Islands, } \\
\text { Maluku Province and Papua Province formerly known } \\
\text { as Irian Jaya), believed to be the original home along } \\
\text { with Bismarck Archipelago (Papua New Guinea), } \\
\text { later spread to Salayar Islands of Sulawesi (in 1912) } \\
\text { and in subsequent years to entire Sulawesi, Bali, Java, } \\
\text { Sumatra }\end{array}$ \\
\hline Malaysia & Recorded (year not known) \\
\hline Maldives & Reported in 1996, distributed in Ari Atol \\
\hline Singapore & Recorded (recent introduction) \\
\hline Taiwan & $\begin{array}{l}\text { Recorded in Pingtung in 1975, spread north and east } \\
\text { to Hualien and Haitung }\end{array}$ \\
\hline Thailand & $\begin{array}{lll}\text { Causes serious damage in Prachuap Khirikan } \\
\text { Province (recent introduction) }\end{array}$ \\
\hline Vietnam & Reported in 1999 \\
\hline American Samoa & Recorded in 1974 \\
\hline Australia & $\begin{array}{l}\text { Recorded around Darwin (Northern Territory) in } \\
1979 \text {, moved eastwards to Cairns \& Cook town and as } \\
\text { far south as Innisfail, reached Queensland. }\end{array}$ \\
\hline French Polynesia & Recorded in 1981 \\
\hline New Caledonia & $\begin{array}{l}\text { Reported in 1942, believed to be present much before } \\
\text { this report }\end{array}$ \\
\hline New Hebrides & Recorded in 1961 \\
\hline North Marina Islands & $\begin{array}{l}\text { Reported in 1948, believed to be present much before } \\
\text { this report, distributed in Saipan and Rota }\end{array}$ \\
\hline Papua New Guinea & $\begin{array}{l}\text { First reported from Bismarck Archipelago, believed to } \\
\text { be the original home along with adjacent Indonesia } \\
\text { (Aru Islands, Maluku Province and Papua Province } \\
\text { formerly known as Irian Jaya) }\end{array}$ \\
\hline Republic of Nauru & Recorded in 2001 \\
\hline Solomon Islands & Reported in 1929 \\
\hline Tahiti & Recorded in 1961 \\
\hline Vanuatu & Reported in 1937 \\
\hline Wallis and Futuna & Recorded in 1987 \\
\hline Western Samoa & Recorded in 1980 \\
\hline
\end{tabular}

Source: Modified and updated from the CABI (1989) Distribution Map No.227 


\section{Development of Brontispa longissima}

Brontispa longissima is one of the most thoroughly studied pests in Indonesia, with work undertaken at Bogor, as well as Bulukumba and Manado (Franssen and Tjoa, 1952).

Adult females lay their $1.4 \mathrm{~mm}$ long and 0.5 $\mathrm{mm}$ wide brown flat eggs in the still-folded leaflets of both young and mature coconut palms. The eggs are surrounded by debris and excrement, and laid longitudinally in an excavated area of leaf tissue in rows of 2 to 4 and sometimes single. They hatch in a minimum and maximum period of 3-4 and 4-7 days respectively.

The 8 to $10 \mathrm{~mm}$ long whitish larva has prominent caliper-like hooks at the hind end. It becomes fully fed in a minimum and maximum period of 23-33 and 43-54 days respectively. The duration of larval period varies greatly in different countries or seasons (probably with temperature): 33-54 days in the New Hebrides (Risbec, 1935); 30-40 days in New Guinea (Froggatt and O'Connor, 1941); 30 days on average in the Solomons (Lever, 1935); and 23-43 days in Sulawesi (Awibowo, 1935). The larvae are fairly sedentary.

The 9 to $10 \mathrm{~mm}$ long and around $2 \mathrm{~mm}$ wide pupa is capable of limited movement, wriggling between the apposed surfaces of the developing leaflets. Pupal stage is completed in a minimum and maximum period of 4 and 5-6 days respectively.

The whole cycle from egg to adult occupies about5-7 weeks in Java and Sulawesi (Kalshoven, 1981; Lever, 1969), but can extend to 9 weeks in some other (presumably cooler) places.

Adult beetle ( 7.5 to $10 \mathrm{~mm}$ long and 1.5 to 2 $\mathrm{mm}$ wide) matures in two weeks time after emergence from the pupa. It lives for 2 to 3 months. The female on an average lays 120 eggs in a course of several weeks (Kalshoven, 1981), which give rise to 40 larvae. The beetles are nocturnal and fly well. They always live in still folded leaflets and move outside only to infest the nearby palms or for mating.

The biology of B. longissima was also studied in Papua New Guinea (O'Connor, 1940; Froggatt and O'Connor, 1941).

\section{Nature and extent of damage}

The larvae and adults shun light, mostly live in the still-folded heart-leaf of preferably young palms feed on the mesophyll of both surfaces of the closely oppressed leaflets, and both stages gnaw long incisions in the tissues, parallel to one another and to the veins of leaflets leaving longitudinal white streaks. Light attacks result in minor leaf injury, and a slight decrease in fruiting at the axils of the damaged leaves. Fruit production is significantly reduced, if eight or more leaves per palm are destroyed.

When the insects are numerous, the incisions are so close to one another that whole of the attacked part of the leaflets are similarly injured, and photosynthesis is reduced to zero.

The unopened fronds of palms up to 4 or 5 years old were most heavily attacked, and trees weakened by attack were more susceptible to drought and disease (Maddison, 1983). In the Solomon Islands, generally, young palms less than about 8-10 years old suffer most (Lever, 1933,1969). Under prolonged outbreak condition, as occurred in South Sulawesi and six other provinces, fruit-shedding takes place, newly-formed leaves remain small, the trees appear ragged, and may ultimately die (Kalshoven, 1981).

Very good account of Brontispa damage is given in Indonesia. In 1912 a serious coconut disorder started on the southern Salayar Islands (South Sulawesi) apparently caused by a group of insects Aleurodicus destructor Mackie, Brontispa longissima, Oryctes rhinoceros Linnaeus and Rhynchophorus ferrugineus Olivier. It was then called 'Salayar disease' or 'coconut disease'. In 1915 it reached the main island of Salayar and then the main island of Sulawesi, spreading across 
South and South-East Sulawesi. The occurrence of Brontispa was probably the result of an accidental introduction; palms weakened by the Brontispa attacks were predisposed to attack of other pest and diseases.

Starting from 1919 the outbreaks or serious infestations have been reported from Indonesia - in South Sulawesi (Hall, 1921), Central Java and South Sulawesi (Hall, 1921a), Central Java (spreading very fast to new areas) (Hall, 1922), East Java and South Sulawesi (Hall, 1924), East Java (Hall, 1925), South Sulawesi (Brontispa presumably in combination with Aleurodicus caused great damage in some areas yield reportedly reduced to 10\%) (Hall, 1926), South Sulawesi (Leefmans, 1927) and East Java (common damage in young plantations) (Leefmans, 1929). In 1929 disastrous Brontispa attacks in coconut plantations and yards were reported in nearly all regions of South East Sulawesi. It sometimes occurred together with $A$, destructor, $O$. rhinoceros and $R$. ferrugineus, which together caused the death of numerous palms, while other palms were in such a bad condition that they produced no fruits for many years. The outbreaks continued until 1935/37 when the situation improved greatly (thanks to biological control). In later years the incidence of Brontispa was comparable with that in Java, i.e., $10-15 \%$ of the trees in certain localities showing injury. The effect of the disastrous infestations was felt for years afterwards, because growers ceased to maintain their plantations during the outbreak years.

The Brontispa attacks in North Sulawesi were generally less severe than those in the South of the Island. Damage was also reported from the Sangihe Islands, on Seram, on the islands Banggai and Labolo of the Banggai group and on the Aru Islands. Brontispa additionally occurred in Bali, but was of little significance. In 1936, Adonaria Island, became a focus for Brontispa attacks, from which the pest migrated to Flores in later years causing particular damage to coconuts in valleys under humid conditions. No trees died but there was loss of yield. The outbreak ended in 1939.
In the regions of Western Java with high rainfall no damage occurred although the beetle has been found. Occasionally some damaged trees were seen in Bantam, near Tanggerang, and in Central Java (Pekalongan, Yogyakarta, Solo).

In East Java, outbreaks of Brontispa occur more regularly, especially near Blitar where about 55.000 trees were damaged in three districts in the dry season of 1940. Brontispa is also a regular pest in Besuki, especially North of Banjuwangi (near Giri) where the climate is rather dry. Outbreaks were also reported from Madura.

Brontispa longissima caused a heavy damage on coconut palms in Sribawano, Central Lampung, $25 \%$ of the sheathes were infested. The average amount of larva and imago per palm was 37 and 62 respectively (Suprapto, 1979).

Brontispa longissima was the eighth serious pest on coconut palm in Indonesia and in the 1980 more than 10,000 ha of coconut palms were attacked by this beetle in 7 provinces (Samino, 1981; Baringbing et al., 1984; Baringbing, 1986).

Brontispa lonngissima is usually not a serious pest in Papua New Guinea (Froggatt and O'Connor, 1941).

As mentioned earlier, in recent times it has spread to Singapore, Vietnam, Nauru, Thailand, Maldives and Hainan Island (China). In the absence of natural antagonists it has become a very serious and devastating pest. Devastation in part of Viet Nam has been very severe. Industry wide losses were approaching 50\% production loss with lots of dead trees.

It is feared that the beetle attack will not be limited to coconut palm, but it will also attack oil palm, betel palm, ornamental palms as well as wild palms and cycads. It may also spread from Maldives to Sri Lanka and southern parts of India to derail the economy of these important coconutgrowing regions of the world. Thus emergency operations are necessary to try to decimate it down in the Maldives. 
The spread of Brontispa longissima and other coconut pests in Oceania is mainly through human activities (Dharmaraju, 1984).

\section{Factors governing abundance}

Dry periods favor the development of Brontispa populations (Bariyah dan Baringbing, 1978; Tjoa, 1953; Kalshoven, 1981) .

In South Sulawesi, the coconut plantations, which were not in good condition due to other causes, i.e., poor soil, infestations by aleurodids, inadequate maintenance, etc., were more susceptible to attack by this pest. The infestation may sometimes supercede earlier attacks of Plesispa.

Large-scale availability of 2-3 years old young palms attracts the pest. Later the heartleaves of older trees become firmer and gradually less suitable as a breeding place for the pest and are no longer penetrated by the beetles.

Poorly-grown palms with a less compact heart are more susceptible to Brontispa attacks. Strong monsoon winds are considered to reduce the influence of parasitic wasps, which triggers the pest attack.

\section{Natural enemies of Brontispa longissima}

The natural enemies recorded are presented in Table 2.

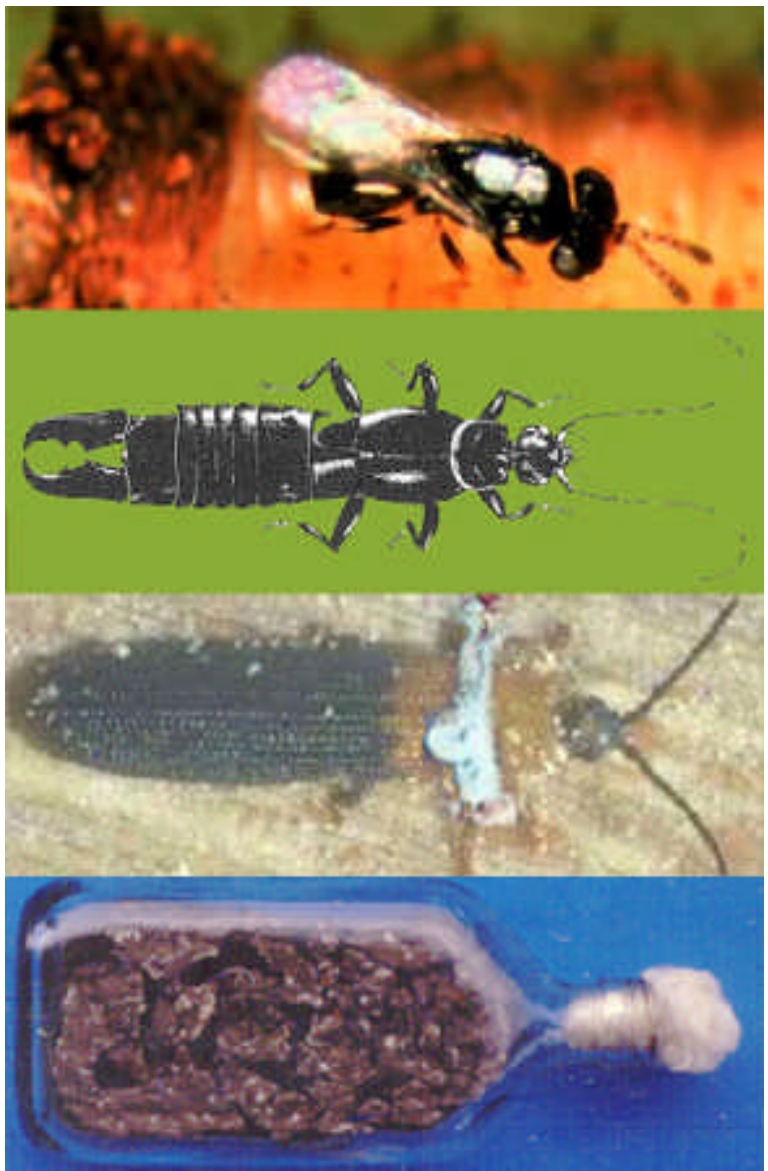

Fig.2. Top to bottom- Tetrastichus brontispae, the most important pupal parasitoid, widely introduced in the distribution zone of Brontispa species, successfully established and providing relief from the pest;

Chelisoches morio, important predator of Brontispa, available in most of its distribution zones;

Metarhizium anisopliae, isolated from $B$. longissima in several places of its distribution and successfully used to control this pest in Western Samoa and Taiwan;

A simple method of producing $M$. anisopliae in empty wine bottles on coconut water from copra industry evolved in India is an excellent example of utilization of industrial waste and converting it to a valuable product 
Table 2. Natural enemies of Brontispa longissima

\begin{tabular}{|c|c|c|}
\hline Species (Order: Family) & $\begin{array}{l}\text { Place of } \\
\text { reporting }\end{array}$ & Remarks \\
\hline \multicolumn{3}{|l|}{ Egg parasitoids } \\
\hline $\begin{array}{l}\text { Hispidophila (Haeckeliana) } \\
\text { brontispae Ferriere } \\
\text { (Hymenoptera: } \\
\text { Trichogrammatidae) }\end{array}$ & $\begin{array}{l}\text { Java, } \\
\text { Indonesia }\end{array}$ & $\begin{array}{l}\text { Described in 1931, one wasp develops per Brontispa } \\
\text { egg, parasitised 15\% egg in the field (Kalshoven, } \\
\text { 1981) }\end{array}$ \\
\hline $\begin{array}{l}\text { Oaencyrtus podontiae Gahan } \\
\text { (Hymenoptera: Encyrtidae) }\end{array}$ & $\begin{array}{l}\text { Java, } \\
\text { Indonesia }\end{array}$ & $\begin{array}{l}\text { Parasitised 10\% eggs (Kalshoven, 1981). In 1941, } \\
\text { Brontispa eggs, parasitised by Ooencyrtus were } \\
\text { introduced from Bogor. Introduced to several } \\
\text { countries for evaluations, recorded in Malaysia. }\end{array}$ \\
\hline $\begin{array}{l}\text { Trichogrammatoidea nana } \\
\text { Zehntner (Hymenoptera: } \\
\text { Trichogrammatidae) }\end{array}$ & $\begin{array}{l}\text { Java, } \\
\text { Indonesia }\end{array}$ & $\begin{array}{l}\text { Described in 1896, successful egg parasitoid of } \\
\text { Brontispa as well as of several other pests. Native to } \\
\text { Java (Indonesia), introduced to Fiji, Papua New } \\
\text { Guinea and Solomon Islands. }\end{array}$ \\
\hline \multicolumn{3}{|l|}{ Larval/pupal parasitoids } \\
\hline $\begin{array}{l}\text { Tetrastichus brontispae } \\
\text { Ferriere } \\
\text { (Hymenoptera: Eulophidae) }\end{array}$ & $\begin{array}{l}\text { Java, } \\
\text { Indonesia }\end{array}$ & $\begin{array}{l}\text { Parasitised } 60-90 \% \text { of the pupae and } 10 \% \text { of the } \\
\text { larvae (Kalshoven, 1981). Considered most effective } \\
\text { species, widely introduced in the Pacific Islands for } \\
\text { the control of Brontispa. }\end{array}$ \\
\hline $\begin{array}{l}\text { Asecodes hispinarum Boucek } \\
\text { (Hymenoptera: Eulophidae) }\end{array}$ & $\begin{array}{l}\text { Western } \\
\text { Samoa }\end{array}$ & $\begin{array}{l}\text { Larval parasitoid of } B \text {. longissima, collected from } \\
\text { Western Samoa and released in Nauru, Viet Nam and } \\
\text { Maldives }\end{array}$ \\
\hline $\begin{array}{l}\text { Chrysonotomyia sp. } \\
\text { (Hymenoptera: Eulophidae) }\end{array}$ & $\begin{array}{l}\text { Western } \\
\text { Samoa }\end{array}$ & $\begin{array}{l}\text { Parasitoid was the most important cause of larval } \\
\text { mortality, parasitising } 75 \% \text { of the } 4^{\text {th }} \text { instar larvae } \\
\text { collected from Western Samoa }\end{array}$ \\
\hline \multicolumn{3}{|l|}{ Entomopathogenic fungi } \\
\hline $\begin{array}{l}\text { Metarhizium anisopliae } \\
\text { (Metchnikoff) Sorokin } \\
\text { (Moniliales : Moniliaceae) }\end{array}$ & $\begin{array}{l}\text { Western } \\
\text { Samoa }\end{array}$ & $\begin{array}{l}\text { Widely distributed soil inhabiting entomopathogenic } \\
\text { fungus. Isolated from B. longissima in several places } \\
\text { of its distribution and successfully used to control this } \\
\text { pest in Samoa and Taiwan }\end{array}$ \\
\hline $\begin{array}{l}\text { Beauveria bassiana } \\
\text { (Balsamo)Vuillemin } \\
\text { (Moniliales : Moniliaceae) }\end{array}$ & $\begin{array}{l}\text { Western } \\
\text { Samoa }\end{array}$ & $\begin{array}{l}\text { Common fungi, spraying of coconut trees with } 5 \times 10^{5} \\
\text { conidia/ml effective against adults and larvae }\end{array}$ \\
\hline \multicolumn{3}{|l|}{ Predator } \\
\hline $\begin{array}{l}\text { Chelisoches morio Fabricius } \\
\text { (Dermeptera:Chelisochidae) }\end{array}$ & $\begin{array}{l}\text { Java, } \\
\text { Indonesia }\end{array}$ & $\begin{array}{l}\text { Important predator of Brontispa, available in most of } \\
\text { its distribution zones }\end{array}$ \\
\hline
\end{tabular}




\section{Tetrastichus brontispae based biological control for Brontispa}

Tetrastichus (Tetrastichodes) brontispae was described from Brontispa longissima (Ferriere, 1933). It is chief among the natural enemies, parasitises the larval and pupal stages. It is native to Java, Indonesia. During 1941 it was also recorded in Bali and Papua Province, not key parasitoid in the east corner of Java and missing in Sulawesi. It has been widely introduced in the Pacific Islands for control of Brontispa species.

Tetrastichus brontispae can parasitise 24$96 \mathrm{hr}$ old pupae in the insectary, but the suitable stage for offering to female wasps in mass production programme is freshly formed pupa up to $24 \mathrm{hr}$ old. T.brontispae was mass-produced by exposing young pupae to the female parasitoid (2 per pupae) for 2 days in test tubes or clear plastic or acrylic containers and each batch of the parasitised pupae were kept separately for development of the parasitoid. Adult parasitoids were fed with $10 \%$ honey offered on cotton wicks. In Indonesia, up to 28 eggs were laid per host, which hatched after 2 days. Larval development took 6-8 days and the pupal stage 7-11 days (Tjoa, 1965). From each parasitised pupa up to 20 parasitoids emerged successfully (Anonymous, 1985). For one developmental cycle of host two generations of $T$. brontispae developed.

In Taiwan, the egg, larval and pupal developmental periods at $21^{\circ} \mathrm{C}$ were $2-3,5-6$ and 10-11 days, respectively. The adult lifespan was 10.8 days for females and 3.6 days for males (Chiu et al., 1985). Under controlled conditions $\left(21^{\circ} \mathrm{C}\right.$ and $\left.70-80 \% \mathrm{RH}\right)$ the life cycle was completed in 19-21 days. Adult male and female longevities were 11.6 and 14.1 days, respectively. The sex ratio was 3.5 females to 1 male (Chiu et al., 1988).

Studies on the utilization of the parasitoid are given country wise.

\section{Indonesia}

Leefmans propagated the use of biological control of B. longissima in 1920, as it was apparent that in Java populations of $B$. longissima were often regulated naturally by a combination of parasitoids, while in the islands north and east of Java, the pest was much more serious. Investigations on the parasitoids, demonstrated that $T$. brontispae was the most effective (Leefmans, 1935).

A mass-rearing facility for $T$. brontispae was developed at Bogor, which provided 2500 Brontispa pupae parasitized by T. brontispae for distribution to the most threatened regions of Sulawesi (Manado, North Sulawesi) in 1932 (May to August).

Distribution of the parasitoids in the field was done using pieces of bamboo in which 4 parasitized pupae were placed. The bamboos were hung on coconut fronds. Four bamboos per hectare were recommended every 3-6 months. It achieved a parasitism rate of 60 and $90 \%$ (in two locations) within 4 months and brought an outbreak in Mapanget under control. From Manado it was brought to Tagulandang (Sangihe lsland) where it also became established. (Leefmans, 1935 ;Kalshoven, 1981).

Many thousands of T.brontispae were released in different parts of East Java (near Banjuwangi), between 1932-1937 against B.longissima, but these only led to temporary control.

In 1933, another 3000 pupae were imported (Awibowo, 1935). A total of 7000 parasitized pupae were introduced into South Sulawesi until 1934 (Leefmans, 1935). Local improvements in the pest situation were sufficient reason to raise public interest in this particular method of pest control. Late in 1934, a technician, trained at the laboratory at Bogor in survey and mass-rearing, was stationed in South Sulawesi; parasitoids were bred-up in a small field laboratory and parasitised Brontispa pupae were distributed in the main infestation areas. 
During 1935, the number of centres for parasitoid breeding and distribution was raised to five (Makassar, Djeneponto, Sindjai, Salajar, and Muna). By this time, there was no further need to import fresh material from Java, as this could be supplied from the original center in Sulawesi.

In 1936, the local stations each distributed about 30.000 parasitized pupae in their areas. Levels of parasitism of the population of Brontispa rose to $60-90 \%$, and equilibrium between host and parasitoid appeared to be established. Distinct improvements in the conditions and the yield of the coconut trees became apparent in several centers of infestation. A parasitoid rearing station was established in 1936 at Genteng. Later surveys indicated that the parasitoids known in East Java occurred naturally at Blitar and Kediri.

Local flare-ups of Brontispa still occurred in 1937 and 1938, but damage was restricted. The condition of the plantations had changed appreciably by this time: palms in most areas showed fully developed foliage, and yields were generally restored to their former levels. Harvesting was again undertaken and the export of copra was resumed. In previous centers of infestation the percentage of injured trees fell from 50 to $10 \%$. In localities where parasitoid was not distributed in sufficient numbers, renewed activity of Brontispa was noted.

From 1939 onwards, reports mention only minor, local infestation of $3-15 \%$ of the trees, and thus a permanent improvement of the situation was reached.

Another biological control project for Brontispa was started in Adonara, an island East of Flores, which was a center for outbreaks. Initially (1938/39) Tetrastichus appeared to become firmly established and a rearing station was set up on the island. After some time the reports were contradictory: in some sites up to 90\% parasitism was found and in others only $10 \%$. Nevertheless, the damage situation gradually improved in course of years, and after 1941 the distribution of parasitoids was ended; regular monitoring to detect new outbreaks were, however, necessary. In the island of Madura, Brontispa damage became noticeable during 1940 and it was found that Tetrastichus occurred there, but no egg parasitoids were present.

Mass-rearing and distribution at Bogor had been stopped, but in Sulawesi, it was continued, partly because public opinion favored continuation, and additionally as a safeguard against possible sudden outbreaks; in such a case parasitoid breeders were sent to the threatened localities. These activities were continued until 1942.

After the war, in 1945, conditions were almost unchanged: local outbreaks occurred occasionally, but the level of parasitism was about the same as before. The entire programme represented an excellent example of successful biological control.

In 1957 T. brontispa was present in a few areas in East Java. In Central Java T. brontispa was also absent in certain locations (e.g. Wonogiri) whereas it occurred about 20 miles away in Giritontro. If exposed to parasitoids, $B$. longissima. from Giritontro became readily parasitized (68-70\%) but Brontispa from Wonogiri developed parasitoids in only $4 \%$ of the cases. Perhaps there are two strains of Brontispa in Java, of which only one permits the complete development of Tetrastichus (Tjoa, 1965).

To sum up the introductions of T.brontispae against B.longissima in Sulawesi, it started in 1932 and within 3 years a total of 37,500 parasitized pupae were sent from Bogor to Makassar [Ujung Pandang]. Eventually 10 rearing stations were established over South Sulawesi and a total of about 13 million parasitized pupae were reared and released between 1935 and 1941 in various locations. Rate of parasitism among field-collected pupae typically was between 70 and $90 \%$. In 1946 it was most commonly between 20 and $40 \%$. In $1948 / 49$ it was on average about $40 \%$ in 20 locations surveyed. The establishment of Tetrastichus brought Brontispa under control and 
the remaining problems improved with it (Franssen and Tjoa, 1952).

Earwig, Chelisoches morio is an important predator of Brontispa but also feeds on coconut flowers and some other organic materials. The life cycle was found to last 75 to 94 days and adults lived for 3 to 5 months. The nymphal stage consisted of four instars each morphologically distinct. The insect is multi-voltine and lays eggs in groups at intervals of about one month (Balfas and Wikardi, 1982). It was commonly associated with $B$. longissima in majority of coconut plantations and complements Tetrastichus brontispae and other parasitoids.

\section{Papua New Guinea}

Tetrastichus brontispae was imported from the Solomon Islands (origin: Java). Large numbers have been released near Rabaul (New Britain) and parasitized pupae have been recovered. The native egg parasitoid, Trichogrammatoidea nana, larval parasitoid Chrysonotomyia (Achrysocharis) sp., two mites associated with the beetles, one identified as Anoplocelaeno sp. and a larval bacterial disease also complement $T$. brontispae which has already established (O'Connor, 1940; Froggatt and O'Connor, 1941).

\section{Mariana Islands}

Tetrastichus brontispae and Haeckeliana brontispae, obtained from Java (Indonesia) were released in 1948 on Saipan and Rota Island the control of Brontispa. T. brontispae appeared well established by 1954 , sometimes providing up to 90\% parasitism.

\section{Solomon Islands}

Before T. brontispae was released in 1936 against B. longissima in Banika Island (Russell Group) (Lever, 1937) red Gasmasid mite (Celaenopsis sp.) was introduced in Russell Islands (Lever, 1933). T. brontispae was again introduced into the Solomon Islands in 1938, but the outcome was negative. Another introduction in 1968 succeeded. The parasitoid spread over 100 acres by the end of 1969 and was affording at least $70 \%$ parasitism, which was sufficient for effective control. The parasitoid spread rapidly and greatly reduced infestation (Stapley, 1973,1979).

It has not been possible to transfer nests of Oecophylla smaragdina to palms occupied by other ants, which then attack and kill $O$. smaragdina ants (Lever, 1933). But later, the rearing and release of the pupal parasitoid, $T$. brontispae, the removal of ants of the genus Pheidole from coconut palms and the establishment of $O$. smaragdina, which drives out Brontispa and other pests, were recommended (Stapley, 1980).

\section{New Caledonia}

Tetrastichus brontispae was introduced into the Noumea Peninsula, New Caledonia and became established. The rate of parasitism did not exceed $24 \%$ and even the combination of this with fungal diseases and the Dermapterous predator $C$. morio did not keep the incidence of the pest down to a satisfactorily low level (Cochereau, 1969).

\section{Guam}

Tetrastichus brontispae was introduced into Guam in 1974 with shipments from Saipan, New Hebrides, New Caledonia and the Solomon Islands. The parasitoids established and in early 1980 rates of parasitism ranging from 2 to $72 \%$ in different locations were reported (Muniappan et al., 1980).

\section{Tahiti}

In Tahiti, T. brontispae was reared from B. longissima (Gourves et al., 1979). 


\section{Australia}

Tetrastichus brontispae was imported from New Caledonia and released in Darwin. $B$. longissima first appeared in Darwin in 1979. T. brontispae was first introduced into Darwin to control B. longissima in 1982. The initial introduction did not establish, but a new introduction in 1984 established for five years and then died out. T. brontispae was reintroduced into Darwin in 1994 and was established in moderate numbers for two years. Between October 1994 and March 1997, the beetle damage to the coconut palms at the release sites was reduced by $20 \%$. The parasitoid was established in higher numbers at sites that were irrigated with overhead sprinklers. After November 1996, the numbers of $T$. brontispae had diminished and it could not be collected from any of the release sites or nearby areas. The climate in the Top End of the Northern Territory may be responsible for the parasitoid's failure to establish, as it is probably suited to a milder tropical climate (Chin and Brown, 2001). Only in one instance, in the North Queensland, release of the T. brontispae has demonstrated effective control of $B$. longissima. Successful release is dependent on the initial release of large numbers of the parasitoid (Halfpapp, 2001).

\section{Western and American Samoa}

In Western Samoa to get long-term control of B. longissima, $T$. brontispae was mass-released since 1981. Suitability of Metarhizium spore application in protecting young coconut palms from Brontispa was tested in the laboratory, and in the field (Stechmann and Semisi, 1984). During 1984-87 a steady decline in damage from $42.4 \%$ in 1984 to $15.4 \%$ in 1987 was noted, following the release of $T$. brontispae as well as larval parasitoid, Asecodes sp. during 1981-86. The incidence of palms damaged by $B$. longissima in plantations and villages was 4 and 22.9\%, respectively. In American Samoa approximately $74 \%$ of all palms were infested compared with only $14.3 \%$ in Western Samoa. In American and Western Samoa damage to coconut by $B$. longissima was 10 and $1-2 \%$ of the total leaf area. In Western Samoa, Asecodes sp. was an important cause of larval mortality, being present in $37 \%$ of samples, while $T$. brontispae was present in only $3 \%$ of samples. Formicids were present in $20 \%$ and forficulids in $64.1 \%$ of samples, while chrysomelids infected by Metarhizium sp. were found on $12.5 \%$ of sampled trees. No parasitoids were found in American Samoa (Vogele and Zeddies, 1990). An extensive survey of damage to 37000 trees in Western Samoa showed that B. longissima was under control and did not cause any significant yield losses (initial production losses were estimated to be as high as $50-70 \%$ ). The benefit: cost ratio of this project was 3.9:1 during the implementation period (1981-86) and 9.9:1 for 1987-90. The internal rate of return for 1981-90 exceeded $40 \%$ and it is concluded that this project was highly successful (Voegele, 1989). Despite relatively high initial costs of 450000 Western Samoa dollars for the collection, introduction, mass rearing and country-wide release of the parasitoids, positive net returns were already achieved in the 4th year of the project. The internal rate of return exceeds $40 \%$ for a 10-year period. All farmers benefit and there are no additional costs at farm level (Voegele et al., 1989). Of late biological control has been one of the primary methods of managing pest problems in American Samoa since 1954 (Tauili'-ili and Vargo, 1993).

\section{Taiwan}

Ten releases of a total of $11456 T$. brontispae adults were made during January-July 1984 in Chenchinhu, and 7 releases of 4881 parasitoids were made during February-June 1984 in Linbien. The percentage parasitism of pupae recorded from field recoveries at the 2 sites was 21.2-79.2 and 9.3-36.2, respectively. The parasitoid prevented most host larvae from developing into adults at Chenchinhu, whereas at Linbien, chrysomelid populations were not effectively suppressed. The parasitoid has established at distances of $2-8 \mathrm{~km}$ from the release site at Chenchinhu (Chiu et al., 1985) and provided good control of the chrysomelid (Chiu and Chen, 1985). The establishment $T$. 
brontispae as a biological control agent of $B$. longissima in Taiwan was confirmed (Chiu et al., 1988). A programme is at present in progress in Taiwan for controlling $B$. longissima using $T$. brontispae (Chiu and Chien, 1989).

Plesispa reichei Chapuis is occasionally a serious pest of coconut seedlings (Ooi, et al., 1989). Its parasitoids available in North Sulawesi and East Java could be tried against $B$. longissima.

The above evidence clearly showed that $B$. longissima can be brought under control through classical biological control. However, exploratory surveys for parasitoids may be conducted in the origional home of $B$. longissima.

\section{Green muscadine fungus Metarhizium anisopliae}

It is a widely distributed soil-inhabiting entomopathogenic fungus, also called as green muscardine fungus (GMF) due to the green color of the sporulating colonies. The fungus infects and kills the larvae, pupae and adults of $B$. longissima. It is an important controlling agent in dense populations during wet spells.

A local strain of GMF, Metarhizium anisopliae var. anisopliae (MA-1) was isolated from infected samples of $B$. longissima in Taiwan. Mycelial growth of GMF was better in Sabouraud dextrose broth (SDB) or SDB supplemented with yeast extract than in Campbell's and other media. In both liquid and solid phase, V-8 media effectively promoted sporulation of MA-1. The range of optimal temperatures and relative humidities for conidia germination were determinated as $24-30^{\circ} \mathrm{C}$ and $92.5-100 \% \mathrm{RH}$, respectively. In a pathogenicity test, the mortalities of larvae, pupae and adults of the beetle were $100 \%$ when they were inoculated with MA-1 conidia suspension at a density of $2.15 \times 10^{7}$ conidia/ml. Even at a density of 2.17 $\mathrm{X} 10^{3}$ conidia $/ \mathrm{ml}$, the larval mortality still reached $47 \%$ and pupal mortality still reached $60 \%$. Strain MA-1 had a higher virulence on the beetle than another isolate of $M$. anisopliae and Beauveria bassiana. Two field trials of microbial control of the beetle were conducted in the Pingtung area of Taiwan in 1986 and 1987. Brontispa longissima could not be detected after 3 applications of MA-1 formulated as a homogeneous biomass, in granules or in a conidial suspension (Liu et al., 1989).

As mentioned above, isolate MA-1 was highly pathogenic to $B$. longissima, but was sensitive to benzimidazole carbamate fungicide. Using ultraviolet and chemical mutation treatment, a benomyl-resistant isolate, MA-126, was obtained, with a target insect virulence at the same level as that of the parent isolate. Rice grain, soyabean and other agricultural byproducts were used as additives to formulate solid fermentation culture media for spore mass production. Yeast extract, dextrose and Sabouraud broth were used in a submerged fermentation for mycelial production. Several dispersants, protectants and inert carriers were assessed for their influence on conidial germination and viability. Two small-scale field applications of MA-1 and MA-126 conidial preparations were made to coconut palms infested with $B$. longissima in 1986-88. Over 80 000 coconut trees were protected (Liu, 1994; Liu and Grey, 1996). It may be an important controlling agent in dense populations during wet spells.

GMF isolated from B. longissima, was successfully used for the production of destruxin, both solid-state and submerged fermentation produced destruxins after 14 days of inoculation (Hsieh et al., 1998). Cooperation with such industries could facilitate the availability of GMF on a large scale. A simple method of producing $M$. anisopliae in empty wine bottles on coconut water from copra industry evolved in India is an excellent example of utilization of industrial waste and converting it to a valuable product (Singh, 1994). 


\section{Other control options}

\section{Variatal resistance}

B. longissima attack was especially severe on the introduced Mayan coconut variety (Lever,1937) in Solmon Islands but some varieties of coconut showed a high degree of resistance to the beetle. Rennel, a variety from the isolated island of Rennel in the Solomon group was rarely attacked (Stapley, 1980).

\section{Quarantine measures}

A key issue is to stop people carrying palms of any kind from one country to another and from one area to another, as the beetles, eggs, larvae and pupae reside inside the tightly folded leaves. Quarantine measures that can be taken to prevent the entry of such pests are needed (Shiau, 1982). In fact a rigid quarantine of plant pests is emphasized (Dharmaraju, 1984).

\section{Cultural control}

As far as possible phytosanitory measures should be adopted in the plantation. All plants leaving and entering a nursery should be checked for obvious sign of infestations. Infested plants should not be sold, only properly managed, pest free healthy plants should leave the nursery. In the plantation old and dead fronds should be removed and destroyed at regular interval to destroy adult beetles, which hide behind the leaf bases during day.

\section{Chemical control}

In the beginning of the last century, it was usual to combat $B$. longissima by applying by hand a concoction of lead arsenate and bordeaux mixture or of tobacco and soap, but the results obtained were poor (Pagden and Lever, 1935). Many workers were engaged in pouring a mixture of soap and tobacco juice into the young leaves to control the pest in the Solomon Islands. Lead arsenate and Bordeaux mixture was found too toxic to the foliage (Lever, 1933). Subsequently, infested trees were sprayed every
4-6 week with a solution of 0.15 percent dieldrin by means of low-volume knapsack sprayers. DDT at 0.2 percent and chlordane at 0.16 percent were effective, but less persistent than dieldrin. In Solomon Islands, small palms 3-4 years old were sprayed once every two months with dieldrin at 0.15 percent by means of a pressurized sprayer and aluminum lances 4 meters long.

Chemical control of the B. longissima was recommended on young palms, followed by biological control with the $T$. brontispae on three years old palms when spray application become more difficult (Stapley, 1973). Chemical control measures become a routine in the nursery (Stapley, 1980).

Spraying twice with phosdrin with an interval of a week between treatments was recommended. DDT at $0.1 \%$ ensured protection for 4-5 weeks, and dieldrin at $0.025 \%$ for $6-8$ weeks. These two insecticides were more effective than chlordane or toxaphene (Orian, 1961).

In East Java the insecticides, aldicarb (Temik $10 \mathrm{G}), 5 \mathrm{~g}$ per tree; dichlorvos ( Nogos $50 \mathrm{EC}$ ), $0.5 \%$; methidathion (Supracide $40 \mathrm{WP}$ ), $0.2 \%$; fenthion (Lebaycid 50 EC), 0.2\%; quinalphos (Bayrusil 25 EC), 0.3\%; azinophos methyl (Gustathion A 40 EC), 0.1\%; tetrachlorvinphos (Gardona 24 EC), 0.8\%; monocrotophos (Azodrin 60 WSC), 0.5\%; chlorfenvinfos (Birlane 24 EC), $0.8 \%$ and idiofenphos (Nuvanol 50 WP), $0.2 \%$ were applied into the infested heart leaves (Baringbing and Bariyah, 1977). Each tree needed $500 \mathrm{ml}$ diluted insecticide with water.

B. longissima was controlled by spraying to run off with $0.1 \%$ trichlorphon (Anonymous, 1983). For control of B. longissima, deltamethrin (5g/ha), dimethoate $(300-400 \mathrm{~g} / \mathrm{ha})$, endosulfan (400-600g/ha), lindane (4kg/ha), monocrotophos $(400 \mathrm{~g} / \mathrm{ha})$, propoxur $(500 \mathrm{~g} / \mathrm{ha})$ or quinalphos $(1 \mathrm{~kg} / \mathrm{ha})$ is recommended. Cypermethrin (15-20g/ha), diazinon (150-200g/ha), fenitrothion $(400 \mathrm{~g} / \mathrm{ha})$, fenvalerate $(10-15 \mathrm{~g} / \mathrm{ha})$, methidathion $(350 \mathrm{~g} / \mathrm{ha})$ or phosphamidon $(500 \mathrm{~g} / \mathrm{ha})$ may also 
be used but are less effective (Desmier de Chenon, 1987).

Triflumuron has also shown some promise against beetles (Soekarjoto, 1989).Laboratory and field tests in Indonesia in 1989 revealed that diflubenzuron was relatively safe to the parasitoid T. brontispae, as compared to carbaryl (Baringbing and Karmawati, 1992).

In Chiatung area of Taiwan sprays of a mixture of $0.1 \%$ carbaryl and $0.5 \%$ summer oil applied to the newly opening leaf buds gave effective control of $B$. longissima (Wu and Tao, 1976).

The insecticides against $B$. longissima are used in Samoa since 1980 (Stechmann and Semisi, 1984).

Acephate (Orthene 75\% WP), dimethoate (Perfekthion 50\% EC) and methamidophos (Monitor 20\% EC) were injected into 3-year-old coconut palms at 2.5 or $5.0 \mathrm{~g}$ a.i./palm for control of B. longissima in Western Samoa. Treatment did not significantly affect adult or larval mortality or the amount of damage (Bourke, 1986).

B. longissima has developed resistance to aldrin and dieldrin. Moreover, most of the insecticides recommended earlier have been phased out due to their harmful side effects. Chemical control may be required in outbreak areas, from the literature available, it is clear that very little efforts have been made to find out safer chemicals. From the knowledge from other pests and crops, it seems feasible to evaluate pesticides of plant origin, which are ecofriendly and compatible with biological control.

\section{Acknowledgement}

This paper is prepared to serve as a preliminary note to APCC country members to gear up for meeting any eventuality regarding the management of this fast spreading pest. We are grateful to FAO for expressing the need for such a paper and closer interaction.

\section{References}

Anonymous, 1974.Annual report of entomologist for 1974. Ministry of Agriculture and Rural Economy, Solomon Islands, $12 \mathrm{pp}$.

Anonymous, 1983. Recommendations for the control of pests. Department of Primary Industry, Konedobu, Papua New Guinea, 67pp.

Anonymous, 1985. Pengendalian hayati terhadap hama kumbang janur (Brontispa longissima Gestro) menggunakan parasit Tetrasticodes brontispae.[Biological control of the coconut frond beetle (Brontispa longissima Gestro) with the parasite Tetrastichodes brontispae] .Direktorat Jenderal Perkebunan; Direktorat Perlindungan Tanaman Perkebunan (leaflet number 05.57.21.12.85), Jakarta, Indonesia, 8pp.

Anonymous, 1986. Pedoman Pengembangbiakan Musuh Alami Hama Tanaman Kelapa. [Guide for the propagation of natural enemies of coconut pests.] Departemen Pertanian, Direktorat Jenderal Perkebunan, Jakarta, Indonesia, 70 pp.

Awibowo, R. 1935. De klapperkever, Brontispa froggatti var. selebensis Gastro, en zijn biologichesche besrrijding op Celebes (The coconut leaf beetle Brontispa froggatti var. selebensis Gastro \& its biological control in Celebes). Landbouw, Buitenzorg 10: 76-92. .

Balfas, R. and Wikardi, E.A. 1982. Pengamatan biologi cocopet dilaboratorium. [A study of the biology of earwigs (Forfuculidae, Dermaptera) in the laboratory.] Pemberitaan Penelitian Tanaman Industri, Bogor, Indonesia 8(44): 32-34.

Baringbing, B. and Karmawati, E. 1992. Effects of diflubenzuron on the coconut pest Brontispa longissima Gestro and its 
parasite, Tetrastichus brontispae Ferriere. Industrial Crops Res. J. 4(2): 40-43.

Baringbing, W.A. 1986. Coconut pest in Indonesia and their control. University of Hawaii, Department of Entomology, Honolulu, Hawaii, 30 pp.

Baringbing, W.A. and Bariyah, B. 1997. Chemical and biological control of coconut pests in Indonesia. Seminar, paper presented at the Department of Entomology, Tamil Nadu Agricultural University, Coimbatore, India.

Baringbing, W.A, Rumini, W. and Sriwulan, I. 1990. Pengamatan Brontispa longissima Gestro dan musuh alaminya di kebun kelapa P.T. SAFIRA Cirangkasbitung kabupaten Sukabumi. Buletin Baltika No.12,pp.105-108

Bariyah, B. dan Baringbing, W.A. 1987. Hama utama tanaman kelapa. Lembaga Penelitian Tanaman Industri, Bogor, 16 pp.

Bourke,T.V. 1986. Systemic insecticide trunk injection trial against the coconut hispine beetle (Brontispa longissima Gestro). Alafua Agric. Bull. 11(3): 41-44.

CABI, 1989. Distribution maps of pests. Nos. 9, $65,170,227,504,505,506,507,508 . \mathrm{CAB}$ International Institute of Entomology, 56 Queen's Gate, London, SW7 5JR, UK.

Chang, Y.C. and Wickman, B.E. 1991. Integrated pest management of several forest defoliators in Taiwan. In: Proceedings of a Symposium, Towards Integrated Pest Management of Forest Defoliators, Raske, A.G. (Ed.). 18th International Congress of Entomology, Vancouver, Canada in 1988. Forest Ecol. Manage. 39: (1-4): 65-72.

Chin, D. and Brown, H. 2001. Biological control of palm leaf beetle, Brontispa longissima (Gestro) (Coleoptera: Chrysomelidae) with the wasp parasitoid, Tetrastichus brontispae (Ferriere) (Hymenoptera: Eulophidae) in Darwin. Proceedings of the Sixth Workshop for Tropical Agricultural Entomology, Darwin, Australia, 11-15 May 1998. Technical Bulletin Department of Primary Industry and Fisheries, Northern Territory of Australia, No. 288, pp.61-65.

Chiu, S.C. and Chen, B.H. 1985. Importation and establishment of Tetrastichus brontispae, a parasitoid of the coconut beetle, in Taiwan. Special Publication, Taiwan Agricultural Research Institute. No. 19, pp.12-13; In: A Review of the Biological Control of Crop Pests in Taiwan (1981-1984).

Chiu, S.C and Chien, C.C. 1989. Control of Diaphorina citri in Taiwan with imported Tetrastichus radiatus. Fruits, Paris 44: 1, 29-31.

Chiu, S.C., Lai, P.Y., Chen, B.H., Chen, Z.C and Shiau, J.F.1985. Introduction, propagation and liberation of a pupal parasitoid, Tetrastichus brontispae, for the control of the coconut leaf beetle in Taiwan. J. Agric. Res. China 34(2): 213-222.

Chiu, S.C., Chen, Z.C., Chou, L.Y., Chou, K.C. and Chen, C.M.1988. Biological control of coconut leaf beetle in Taiwan. J. Agric. Res. China 37(2): 211-219.

Cochereau, P. 1969. Establishment of Tetrastichus brontispae Ferr. (Hymenoptera, Eulophidae), parasite of Brontispa longissima Gestro, var. froggatti Sharp (Coleoptera, Chrysomelidae, Hispinae) in the Noumean peninsula (Installation de Tetrastichus brontispae Ferr. (Hymenoptera, Eulophidae), parasite de Brontispa longissima Gestro, var. froggatti Sharp (Coleoptera, Chrysomelidae, Hispinae) dans la presqu'ile de Noumea). Cahiers ORSTOM serie Biologie No. 7, pp.139-141.

Desmier de Chenon, R. 1987. La protection raisonnee des cultures ae cocotiers et de 
palmiers a hulles en Indonesie: (Rational protection of coconut and oil palm in Indonesia). Oleagineux 42(6): 223-231.

Dharmaraju, E.1984.Transport and the spread of crop pests in tropical Polynesia, pp. 257-272. In: Commerce and the Spread of Pests and Disease Vectors, M. Laird (Ed.). New York, USA. Praeger Publishers.

FAO, 1981. New records. Quarterly Newsletter. FAO Plant Protection Committee for the South East Asia and Pacific Region 24(1) 4-11.

Fenner, T.L. 1996. Palm leaf beetle. Agricultural Quarantine Service, Darwin, Northern Territory, Australia. Agnote, Darwin, No. 371, 3 pp.

Ferriere, Ch. 1933. Chalcidoid and proctotrupoid parasites of pests of the coconut palm. Stylops 2(4-5): 86-96, 97-108.

Firman, I.D. 1981. Plant protection news. Information-Circular, South Pacific Commission, No. 88, 11 pp.

Franssen, C.J.H. and Tjoa T. M. 1952. Biologische be strijding van de klapperplagen op Zuld-Celebes. (Biological control of the coconut pests in South Sulawesi.) Landbouw (Jakarta, Indonesia) 24(7-12): 319-360.

Froggatt, John L.and O'Connor, B.A. 1941. Insects associated with the coconut palm, Pt. II. New Guinea Agric. Gaz. 7: 125-130.

Gourves, J., Samuelson, G.A., Boheman, C.H. and Fairmaire, H. 1979. The Chrysomelidae of Tahiti (Coleoptera) (Les Chrysomelidae de Tahiti (Coleopteres)). Pacific Insects 20(4): 410-415.

Halfpapp, K. 2001. Introduction of Tetrastichus brontispae for control of Brontispa longissima in Australia. In: Proceedings of the Sixth Workshop for Tropical Agricultural Entomology, Darwin,
Australia, 11-15 May 1998. Technical Bulletin Department of Primary Industry and Fisheries, Northern Territory of Australia, No. 288, 59-60.

Hall, C.J.J.van, 1921. Ziekten en plagen der cultuurgewassen In Nederlandsch-Indie in 1919. (Diseases and pests of crops in the Dutch East-Indies in 1919.) Mededeelingen van het Instituut voor Plantenziekten No. 39, 50pp.

Hall, C.J.J.van, 1921a. Ziekten en plagen der cultuurgewassen In Nederlandsch-Indie in 1920. (Diseases and pests of crops in the Dutch East-Indies in 1920.) Mededeelingen van het Instituut voor Plantenziekten No. 46, 50pp.

Hall, C.J.J.van, 1922. Ziekten en plagen der cultuurgewassen In Nederlandsch-Indie in 1921. (Diseases and pests of crops in the Dutch East-Indies in 1921.) Mededeelingen van het Instituut voor Plantenziekten No. 53, 46pp.

Hall, C.J.J.van, 1923. Ziekten en plagen der cultuurgewassen In Nederlandsch-Indie in 1922. (Diseases and pests of crops in the Dutch East-Indies in 1922.) Mededeelingen van het Instituut voor Plantenziekten No. 58, 42pp.

Hall, C.J.J.van, 1924. Ziekten en plagen der cultuurgewassen In Nederlandsch-Indie in 1923. (Diseases and pests of crops in the Dutch East-Indies in 1923.) Mededeelingen van het Instituut voor Plantenziekten No. $64,47 \mathrm{pp}$.

Hall, C.J.J.van, 1925. Ziekten en plagen der cultuurgewassen In Nederlandsch-Indie in 1924. (Diseases and pests of crops in the Dutch East-Indies in 1924.) Mededeelingen van het Instituut voor Plantenziekten No. 67, 53pp.

Hall, C.J.J.van, 1926. Ziekten en plagen der cultuurgewassen In Nederlandsch-Indie in 
1925. (Diseases and pests of crops in the Dutch East-Indies in 1925.) Mededeelingen van het Instituut voor Plantenziekten No. 70, 51pp.

Harry, W. Lange Jr. 1950. The biology of Mariana beetle, Brontispa mariana Spaeth, on Saipan and introduction of parasites from Malaya and Java for its control. Proc. Hawaiian Entomol. Soc. 14 (1): 143-146.

Hassan, E. 1972. Problems of applied entomology in Papua New Guinea (Probleme der angewandten Entomologie in Papua und Neu-Guinea). Anzeiger fur Schadlingskunde und Pflanzenschutz. 45 (9):129-134.

Heroetadji, H. 1989. Parasite of Plesispa reichei anad Brontispa longissima in East Java. In: UNDP/FAO Integrated Coconut Pest Control Project. Annual Report 1989.CRI, Manado, North Sulawesi, Indonesia ,pp.9296.

Hollingsworth, Meleisea, S. and Iosefa, T. 1988. Natural enemies of Brontispa longissima (Gestro) in Western Samoa. Alafua Agric. Bull. 13(1): 41-45.

Hosang, M.L.A, Sabbatoellah, S.,Tumewan, F. and Alouw, J.C. 1995. Musuh alami hama Brontispa longissima Gestro.. Prosiding Seminar Regional Balai Penelitian Tanaman Kelapa dan Palma lain, pp.30-38

Hosang, M.L.A.1996. Patogenisitas Cendawan Beauveria bassiana (Balsamo) Vuillemin terhadap Brontispa longissima Gestro(Coleoptera : Hispidae). Jurnal Penilitian Tannaman Industri( Industrial Crops Research Journal ) 2(1):8-19

Hou, R.F. 1997. Recent progress in microbial control of insects in Taiwan. Plant Prot. Bull., Taipei 39(1): 75-84.

Hsieh, C.Y., Hung, W.K., Kao, S.S., Wang, S.C. and Tzeng, Y.M. 1998. Production of destruxins from a local entomopathogenic fungus, Metarhizium anisopliae var. anisopliae, by solid-state and submerged fermentation. J. Chinese Agric. Chem. Soc. 36(4): 371-379.

Hunter, D. and Zuhir, M. 1996. Coconut, arecanut, and spice crops in Maldives: status and prospects. J. Plan. Crops 24 (1): $1-8$.

Kalshoven, L.G.E. 1981. Pest of Crops in Indonesia. Revised and translated into English by P.A. van der Lann. PT. Ichtiar Baru-Van Houve, Jakarta, 701 pp.

Lau, C.S.K. 1991. Occurrence of Brontispa longissima Gestro in Hong Kong. Quarterly Newsletter Asia and Pacific Plant Protection Commission 34 (3-4): 10.

Leefmans, S. 1927. Ziekten en plagen der cultuurgewassen In Nederlandsch-Indie in 1926. (Diseases and pests of crops in the Dutch East-Indies in 1926.) Mededeelingen van het Instituut voor Plantenziekten No. 73, 60pp.

Leefmans, S. 1929. Ziekten en plagen der cultuurgewassen In Nederlandsch-Indie in 1928. (Diseases and pests of crops in the Dutch East-Indies in 1928.) Mededeelingen van het Instituut voor Plantenziekten No. 75, 96pp.

Leefmans, S. 1933. Ziektenen plagen der cultuurgewassen In Nederlandsch OostIndie in 1930. (Diseases and pests of crops in the Dutch East-Indies.) Mededeelingen van het Instituut voor Plantenziekten No. 81, 84pp.

Leefmans, S. 1934. Ziektenen plagen der cultuurgewassen In Nederlandsch OostIndie in 1931. (Diseases and pests of crops in the Dutch East-Indies in 1931.) Mededeelingen van het Instituut voor Plantenziekten No. 82, 92pp 
Leefmans, S. 1935. Biologische bestrijding van insectenplagen in Nederlaandsch-Indie door lnterlnsulaire overbrenging van parasieten. [Biological control of insect pests in the Dutch East-Indies through Inter-island transfer of parasites.] Landbouwkundig Tijdschrift 47(571): 209-219.

Lever R.J.A.W. 1933. Status of economic entomology in the British Solomon Islands. Bull.Entomol.Res. 24: 253-256

Lever, R.J.A.W. 1934. Insects of the coconut palm in the British Sol. Islands. List 3. Brit. Solomon Is. Agric. Gaz. 2(3): 7-8.

Lever, R.J.A.W. 1936. Control of Brontispa in Celebes by Tetrastichodes. Brit. Solomon Islands Agric. Gaz. 3(4): Supplement, 6.

Lever, R.J.A.W.1937. Economic Insects and biological conlrol in the British Solomon Islands. Bull. Entomol. Res. 28: 325-331

Lever, R.I.A.W. 1969. Pests of Coconut Palm. Food and Agriculture Organization of the United Nation, Rome 190 pp.

Liu, S.D. Lin, S.C. and Shiau, J.F. 1989. Microbial control of coconut leaf beetle (Brontispa longissima) with green muscardine fungus, Metarhizium anisopliae var. anisopliae. J. Invert. Pathol. 53(3): 307-314.

Liu, S.D. 1994. The application of fungicide resistant entomopathogenic green muscardine fungus in Taiwan: biological control of coconut leaf beetle (Brontispa longissima) and diamondback moth (Plutella xylostella). Technical Bulletin Food and Fertilizer Technology Center, No. 138, 10 pp.

Liu, S.D. and Grey, G. 1996. The application of fungicide resistant entomopathogenic green muscardine fungus in Taiwan: biological control of coconut leaf beetle (Brontispa longissima) and diamondback moth
(Plutella xylostella), pp. 154-163. In : Biological Pest Control in Systems of Integrated Pest Management- Proceedings of the International Symposium on The use of Biological Control Agents under Integrated Pest Management,

Maddison, P.A. 1983. Coconut hispine beetle. Advisory Leaflet, South PacificCommission, No. 17, 4 pp.

Muniappan, R., Duenos, J.G. and Blas, T. 1980. Biological control of the Palau coconut beetle Brontispa palauensis (Esaki and Chujo), on Guam. Micronesia 16 : 359-360.

O'Connor, B.A.1940. Notes of the coconut leaf hispid, Brontispa froggatti Sharp and its parasites. New Guinea Agric. Gaz. 6: 36-40.

Ooi, P.A. C., Soekarjoto, S., Sabbatoellah, F. Tumewan and Heroetadji Hoesni, R. 1989. Plesispa reichei and its parasitoids Indonesia. In: Integrated Coconut Pest Control. Project Annual Report. Coconut Research Institute, Manado, Indonesia, pp.85-91.

Orian, A.J.E.1961.Notes on the Hispine beetle Brontispa limbata (Waterh). Rev. Agric. Sucr. Maurice 40(4): 193-195.

Pagden, H.T. and Lever, R.J.A.W. 1935. Insects of the coconut palm in the Brit. Solomon Islands. Brit. Solomon Islands. Agric. Gaz. 3(1): 2-22.

Risbec, J.1935.Note preliminare sur les principaux parasites du cocotier aux Nouvollec-Hebrides. Ann. Entomol., France 104: 159-173.

Semisi, S.T., Braune, H., Peters, A.M., Iosefa, T. and Waage, J.K. 1992. Integrated pest management in Western Samoa, pp.383398. In: Integrated pest Management in the Asia-Pacific Region, P.A.C. Ooi, G.S. Lim, 
T.H. Ho and P.L. Manalo (Eds.). CAB International, Wallingford, U.K

Shiau, J.F. 1982. Introduced diseases and insect pests of agricultural crops and their treatment in Taiwan. Plant Prot. Bull., Taiwan 24(2): 89-99.

Singh, S.P. 1994. Technology for Production of Natural Enemies. Project Directorate of Biological Control (ICAR), Bangalore, India, $221 \mathrm{pp}$.

Soekarjoto, 1989. Kajian beberapa insektisida penghambat sintesis pada berbagai stadium kumbang Janur kelapa Brontispa longissima (Gestro) di laboratorium. [Laboratory trials with several chitin synthesis inhibitors to control coconut beetle Brontispa longissima]. Jurnal Penelitian Kelapa, Manado, Indonesia 3 (2): 61-70.

Stapley, J.H. 1973. Insect pests of coconuts In the Pacific region. Outlook on Agriculture 7(5): 211-217.

Stapley, J.H. 1979. Notes on biological control in the Solomon Islands.

Stapley, J.H. 1979? Annual report of entomologist 1978. Ministry of Agriculture and Lands, Solomon Islands, $127 \mathrm{pp}$.

Stapley, J.H. 1980. Coconut leaf beetle (Brontispa) in the Solomons. Alafua Agricultural Bulletin 5(4): 17-22.

Stapley, J.H.1973. Insect pests of coconuts in the Pacific region. Outlook on Agriculture 7(5): 211-217.

Stechmann, D. H. and Semisi, S.T. 1984. Insektenbekaempfung in West-Samoa unter besonderer Beruecksichtigung des Standes biologischer and Integrierier Verfahren. [Insect pest control in Western Samoa with special reference to present status of biological and Integrated control measures]
Anz Schaedlingkde., Pjlanzenschutz Umweltcchutz 57:65-70.

Suprapto, 1983. Pengaruh serangan Brontispa longissima terhadap produksi kelapa [The effect of Brontispa longissima infestations on coconut production] Pemberitaan Penelitian Tanaman Industri Bogor, Indonesia 8(45): 17-21.

Tauili'-ili, P. and Vargo, A.M. 1993. History of biological control in American Samoa. Biological Control of Exotic Pests in the Pacific. Proceedings of a Plenary Session and Symposium, XIX International Congress of Entomology, Beijing, June 1992. Micronesica, No. 4 suppl., 57-60.

Tjoa, T.M.1965. The occurrence of two strains of Brontispa longissima (Gestro) (Col. Hispidae) based on resistance or non-resistance to the parasite Tetrastichus brontispae (Ferrier) (Hym., Eulophidae) in Java. Bull. Entomol.Res. Indonesia 55(4): 619-614.

Tjoa, T.M. 1953. Memberantas hama-hama kelapa dan kopra. NoordhoffKolff, Djakarta, 270 pp.

Tumewan, F. and Hosang, M.L.A. 1998. Pemanfaatan parasitoid dan patogen pada hama Brontispa longissima Gestro,pp.631637. Prosiding Konperensi Nasional Kelapa IV, Bandar Lampung, 21-23 April 1998.

Voegele, J.M. 1989. Biological control of Brontispa longissima in Western Samoa: an ecological and economic evaluation. Agriculture, Ecosystems and Environment 27(1-4): 315-329; In: Proceedings of an International Symposium on Agricultural Ecology and Environment, Padova, Italy, 5-7 April 1988.

Voegele, J.M., Klingauf, F. and Engelhardt, T. 1989. Studies on the economic returns of biological pest control with a case study 
from Western Samoa (Untersuchungen zur Wirtschaftlichkeit des biologischen Pflanzenschutzes anhand eines Fallbeispiel aus West-Samoa). Gesunde-Pflanzen 41(7): 255-258.

Vogele, J.M. and Zeddies, J. 1990. Economic analysis of classical biological pest control: a case study from Western Samoa.In : Proceedings: Integrated Pest Management in Tropical and Subtropical Cropping Systems '89, No. 1, pp. 45-51.

Woodroof, J.G. 1979. Coconuts: production, processing, products. Ed. 2, xi +307 pp.

Wu, K.C and Tao, C.C.C. 1976. Natural enemies of the transparent scale and control of the leaf bud beetle attacking coconut palm in Taiwan. J. Agric. Res. China 25(2): 141155. 